\title{
Distribution of Microfossils in the Vendian Deposits of the Orsha Depression of the East European Platform, Belarus
}

\author{
E. Yu. Golubkova ${ }^{a, *}$, O. F. Kuzmenkova ${ }^{b}$, E. A. Kushim ${ }^{a}$, A. G. Laptsevich ${ }^{b}$, \\ S. S. Mankievič ${ }^{b}$, and Yu. V. Plotkina ${ }^{a}$ \\ a Institute of Precambrian Geology and Geochronology, Russian Academy of Sciences, St. Petersburg, 199034 Russia \\ ${ }^{b}$ Research and Production Center for Geology, Branch of the Institute of Geology, Minsk, Belarus \\ *e-mail: golubkovaeyu@mail.ru \\ Received January 4, 2021; revised February 13, 2021; accepted April 17, 2021
}

\begin{abstract}
The complete sections of the Lower and Upper Vendian of the East European Platform were opened in the boreholes of Belarus. This allows us to consider this region as a stratotype area. In order to update the paleontological characteristics of the Vendian, organic-walled microfossils from the Bogushevsk-1, Bogushevsk-2 (Liozno), and Lepel-1 reference boreholes drilled in the north of the Orsha Depression were studied. The transitive assemblage I with Leiosphaeridia minutissima-Leiosphaeridia tenuissima was recognized in the Lower Vendian Liozno Formation of the Volyn Series and the Upper Vendian Kotlin Formation. The Redkino microfossil assemblages were identified at three stratigraphic levels in the Nizy, Selyava, and Chernitsa formations: assemblage II with Morania zinkovi, assemblage III with Morania zinkovi-Tynnia precambrica, and assemblage IV with Morania zinkovi-Tynnia precambrica-Striatella coriacea, respectively. The Kotlin assemblage V with Vendotaenia antiqua-Primoflagella speciosa was distinguished in the upper part of the Kotlin Formation (Bogushevsk-1 borehole). On the basis of the taxonomic composition, assemblages III and IV are correlated with the first Redkino biota of the Starorusskaya Formation; assemblage V is correlated with the third Kotlin biota of the Vasileostrovskaya Formation of the northwestern part of Russia. Our data show a high biostratigraphic potential of organic-walled microfossils, which should be used to substantiate regional stratigraphic units of the Upper Vendian in the updated stratigraphic scheme of the East European Platform.
\end{abstract}

Keywords: microfossils, biostratigraphy, East European Platform, Belarus, Vendian

DOI: $10.1134 / \mathrm{S} 0869593821060034$

\section{INTRODUCTION}

The Vendian deposits were studied most actively in the 1960s-1980s (Fedonkin, 1981; Rifei..., 1976; Sokolov, 1974, 1980; Vendskaya..., 1985a, 1985b; Volkova et al., 1979). As a result of these studies, the territory of the west and northwest of the East European Platform (EEP), including Ukraine (Volhynia and Podolia), Belarus, the Baltic countries, and the north of European Russia was assumed to be the stratotype locality of the development of the Vendian deposits (Sokolov, 1974; Vendskaya..., 1985b). Of particular importance for stratigraphy are the sections of Belarus, where the complete Vendian-Lower Cambrian terrigenous sequences are exposed. Regional stratigraphic charts (RSC) of the Vendian adopted for Belarus (Geologiya..., 2001; Makhnach et al., 2005a; Stratigraficheskie..., 2010) and European Russia (Postanovleniya..., 1992; Semikhatov et al., 1991; Stratigraficheskaya..., 1996) largely coincide in terms of the principles of recognition, volume, and paleontological content (Fig. 1). The Vendian in adjacent areas is subdivided into two subdivisions-lower and upper. On the basis of historical geological data, glacial deposits of the Vilchanka Series and volcanogenic sedimentary strata of the Volyn Series are attributed to the lower division. In the RSC of Russia, these deposits are attributed to the Lapland Regional Stage (without the upper part of the Volyn Series; Stratigraficheskaya..., 1996). On the basis of micropaleontological data, the terminal stratum of the Volyn Series in the unified scheme of Belarus is assigned to the new Liozno Regional Stage (Fig. 1; Stratigraficheskie..., 2010). The age of the Vilchanka Series is not strictly defined. According to various data, it is correlated with the Marinoan (630 Ma) and Gaskiers (580 Ma) glacial events (Semikhatov et al., 2015; Zaitseva et al., 2019) or only the Gaskiers event (Grazhdankin, 2014; Grazhdankin and Maslov, 2015). The Volyn Series in Ukraine and Belarus is represented by the thick trap stratum composing the large Volyn-Brest Magmatic Province (Kuzmenkova et al., 2010). Intrusive rocks contain zircon grains varying in age from $573 \pm 14$ to $551 \pm 4$ Ma (Compston, 1995; Nosova et al., 2010; Shumlyanskyy et al., 2016; etc.). The recent $\mathrm{U}-\mathrm{Pb}$ dates of zircons from tuffs of the Kobryn-1k and Pinsk26 boreholes in Belarus have shown that the age of traps of the Volyn Series corresponds to the age interval from $579 \pm 4$ to $545 \pm 4$ Ma (Paszkowski et al., 2019). 


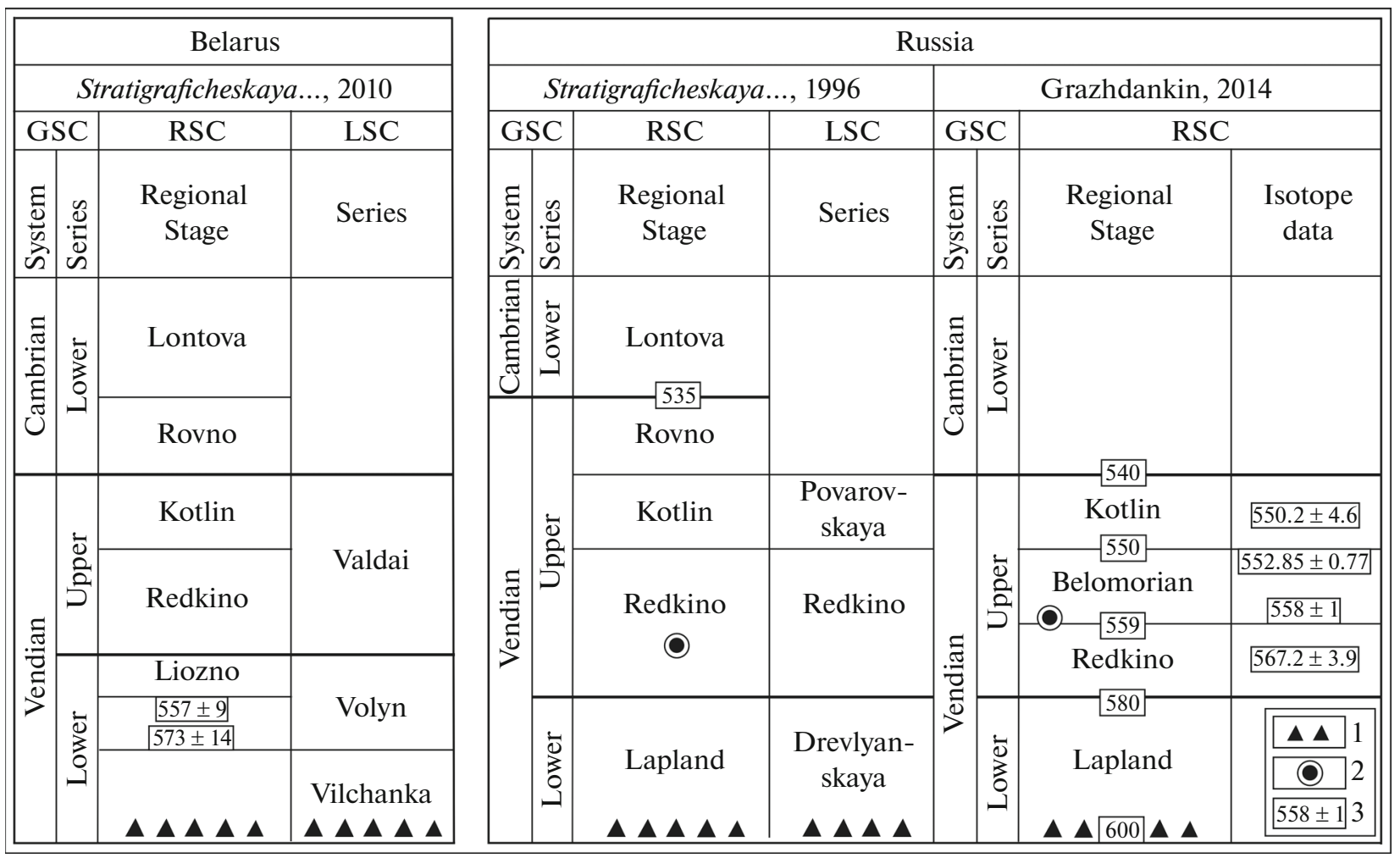

Fig. 1. Correlation of regional stratigraphic schemes of the Vendian of Belarus and European Russia. (1) Glacial deposits, (2) Ediacaran soft-bodied organisms, (3) U-Pb age of zircons from intrusive rocks. Abbreviations: GSC-General Stratigraphic Chart, RSC-Regional Stratigraphic Chart, LSC-local stratigraphic chart.

The upper division of the Vendian of Belarus and Russia was subdivided according to paleontological data (Fedonkin, 1981; Gnilovskaya et al., 1988; Mikrofossilii..., 1989; Piskun, 2013; Vendskaya..., 1985a; Volkova et al., 1979; etc.). On the basis of analysis of the distribution of soft-bodied organisms, macroscopic algae, and microfossils in sections of European Russia, three regional stages were distinguished: Redkino, Kotlin, and Rovno (Semikhatov et al., 1991; Sokolov, 1997; Stratigraficheskaya..., 1996; Vendskaya..., 1985b). The U-Pb ages of tuffogenic zircons from volcanic tuffs of the Redkino Regional Stage of the Southeastern Belomorian Region and the Perevalok Formation in the Middle Urals are 567.2 \pm 3.9 and from $558 \pm 1$ to $552.85 \pm 0.77 \mathrm{Ma}$, respectively (Fig. 1; Grazhdankin, 2014; Grazhdankin and Maslov, 2015a; and references in these works). The overlying Mezen Formation (Erga Formation in the scheme of Grazhdankin (2003)) of the Southeastern Belomorian Region is attributed to the Redkino Regional Stage; volcanic ash interbeds contain zircon grains with the age of $550 \pm 4.6 \mathrm{Ma}$ (Grazhdankin, 2014). In the RSC of Russia, the Vendian-Cambrian boundary is distinguished on the basis of the change of the Rovno assemblage of fossil microorganisms to the Lontova one (Vendskaya..., 1985a; Volkova et al., 1979). This boundary was established at the turn of $535 \mathrm{Ma}$ (Dopolneniya..., 2000). The Redkino and Kotlin regional stages in the Belarus stratigraphic scheme are attributed to the Upper Vendian. The PrecambrianCambrian boundary at the base of the Rovno Regional Stage is based on the paleontological and lithological data (Makhnach et al., 1985, 2005b; Stratigraficheskie..., 2010). In general, it coincides with that in the International Chronostratigraphic Chart (538.8 Ma; Braiser et al., 1994; Gehling et al., 2001; Gradstein, 2020; Landing, 1994; Narbonne et al., 2012).

Recently, D.V. Grazhdankin proposed a new RSC for the Upper Vendian of European Russia, which included the Redkino, new Belomorian, and Kotlin regional stages (Fig. 1; Grazhdankin, 2014; etc.). The Belomorian Regional Stage was distinguished on the basis of the mass distribution of Ediacaran soft-bodied organisms. The scheme was developed on the basis of studying the sections of the Southeastern Belomorian Region and the Middle Urals. However, its use in the northwest of Russia and Belarus is still impossible owing to the lack of imprints of soft-bodied organisms on this territory. Also, the biostratigraphic criteria for distinguishing the Redkino Regional Stage in its reduced volume are not yet fully understood (Fig. 1). At the same time, the new scheme has a significant advantage, as it provides clear age limits for established regional subdivisions.

The paleontological method is the leading one in the subdivision of the Upper Vendian-Lower Cambrian 
terrigenous sequences of the EEP. The study of stratotype sections at a qualitatively new level and using the latest techniques could allow us to develop unified biostratigraphic criteria for justifying the volumes and boundaries of general and regional divisions and, finally, to propose a unified RSC for the territories of Belarus and Russia. However, in order to resolve the existing differences and update the paleontological characteristics of the selected stratigraphic units, a detailed restudy of the reference Vendian sections of the EEP is required. This article, the first in a series of works on adjacent territories, is aimed at solving this problem.

\section{GEOLOGICAL REVIEW}

In the Late Precambrian, there was a vast NE-trending Volyn-Orsha Trough, a part of the system of MidRussian aulacogens, in the southwest of the EEP. In the modern structural plan, it coincides with the Volyn Depression (Ukraine), Lukov-Ratno Horst, Paliessie Saddle, Pripyat Trough, Belarusian Anteclise, Zlobin Saddle, and Orsha Depression (Belarus) (Fig. 2). The trough was formed at the Early Baikalian stage and inherited the position of the structures of the crystalline basement-the Central Belarusian Suture Zone and the Osnitsa-Mikashevichi Volcano-Plutonic Belt (Geologiya..., 2001). In the Early Vendian period, the "tongues" of the continental Varanger glaciation from the north entered a relict depression inherited from the Volyn-Orsha, which led to the formation of the cover glacial formations of the Vilchanka division. During the breakup of the Rodinia supercontinent at the Late Baikalian stage, a large Volyn-Brest Magmatic Province was formed in the southwest of Russia (Makhnach and Veretennikov, 1970, 2001; Nosova et al., 2008; Rifei..., 1976). This stage was characterized by the accumulation of Riphean terrigenous strata, which were isolated in the Sherovichi and Belorussian series (Rifei..., 1976; Stratigraficheskie..., 2010). The Kobryn-Mogilev Paleotrough, which inherited the position of the Volyn-Orsha Paleotrough and significantly expanded to the northwest, was connected to the area of active volcanism from the northeast. At that time, trap volcanism was manifested in the southwest of the territory in subaerial conditions, and volcanic sedimentary strata of the Volyn Series accumulated in the aquatic and coastal-marine environments in the northeast. In the Late VendianEarly Cambrian, there was an extensive KobrynPolack Paleotrough in the territory of modern Belarus, where terrigenous, mainly clayey-silty deposits accumulated (Geologiya..., 2001).

Within the Orsha Depression, the Vilchanka Series is represented by glacial (tillites), glacial-river (sands, sandstones), and lacustrine-glacial (silty-clayey deposits) deposits of the Glussk and Blon formations (Fig. 2; Rifei..., 1976; Shkuratov and Makhnach, 2003). The overlying Volyn Series is composed of terrigenous and volcanogenic sedimentary deposits of the Lukoml Formation and volcanomictic, clayeysilty strata of the Liozno Formation. The Lukoml Formation is followed in southwestern direction by volcanic tuffs and tuffites of the Klets Formation, which are further to the southwest are gradually followed by effusive rocks and tuffs of the Rataichitsy Formation (Geologiya..., 2001; Stratigraficheskie..., 2010).

The terrigenous strata of the Valdai Series are distributed in the north and southwest of Belarus. The complete stratigraphic formations subdividing into four sedimentation cycles were distinguished in the Orsha Depression. The first three formations (Nizy, Selyavy, and Chernitsa) are attributed to the Redkino Regional Stage, and the fourth one (Kotlin Formation) is attributed to the Kotlin Regional Stage (Makhnach and Veretennikov, 2001; Stratigraficheskie..., 2010).

\section{MATERIALS AND METHODS}

We analyzed the core sections of the deep parametric Bogushevsk-1, Bogushevsk-2 (Liozno), and Lepel-1 boreholes, drilled in the 1960s-1970s in the north of the Orsha Depression (Fig. 2). In total, 78 core samples were collected from gray and green clays, mudstones, and siltstones for paleontological study. Organic-walled microfossils were extracted from rocks using the conservative technique that excludes the stage of centrifugation. Samples were processed in concentrated hydrofluoric acid (HF) to remove $\mathrm{Si}-$ bearing minerals and then washed in distilled water. The separation of the precipitate from fluorides was carried out at the next stage by dissolving in a $10 \%$ solution of hydrochloric acid $(\mathrm{HCl})$. The resulting precipitate was washed with distilled water and passed through a $10 \mu \mathrm{m}$ sieve to remove the fine suspension.

Then, the organomacerate was studied under a Bresser Advance ICD binocular microscope. Organic remains were pipetted onto a slide and preserved with Eukitt polyester. For control, traditional palynological preparations were made from the remaining residue in the same conservation environment. The further study was carried out under an AxioScope.A1 (Carl Zeiss) biological microscope. Images of microfossils were taken in transmitted light with an Axiocam MRc5 camera. A detailed study of the morphological features of microfossils was carried out using a TESCAN VEGA3 scanning electron microscope at an accelerating voltage of $12 \mathrm{kV}$ and a magnification range from $\times 30$ to $\times 67000$ in the Laboratory of Isotope Geology of the Institute of Precambrian Geology and Geochronology, Russian Academy of Sciences. The samples were covered with a gold film $(\approx 100 \AA$ thick $)$.

The collection of macrofossil remains and permanent palynological preparations from the core sections described in the present paper is stored in the Laboratory of Lithology and Biostratigraphy of the Institute of Precambrian Geology and Geochronology (St. Petersburg). 


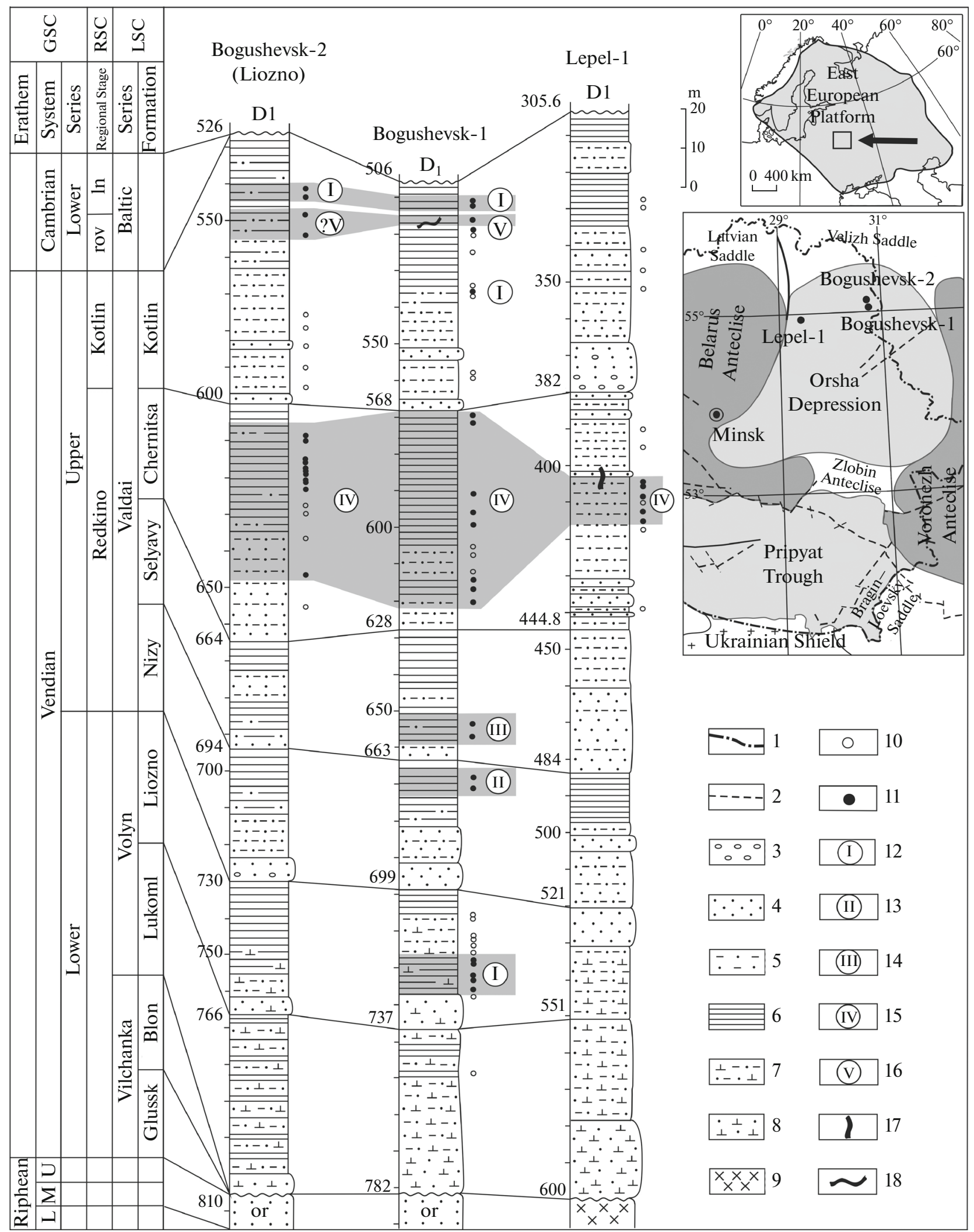


Fig. 2. Distribution of microfossil assemblages in the Vendian seq uences of the Orsha Depression. (1) Border of Belarus; (2) regional faults; (3) gravellites; (4) sandstones; (5) siltstones; (6) clays, mudstones; (7) tuff siltstones; (8) tuff sandstones; (9) Archean-Lower Proterozoic crystalline basement; (10) microfossil-free specimens; (11) specimens with microfossils; (12) transitive assemblage I with Leiosphaeridia minutissima-Leiosphaeridia tenuissima; (13-15) Redkino assemblages: (13) assemblage II with Morania zinkovi, (14) assemblage III with Morania zinkovi-Tynnia precambrica, (15) assemblage IV with Morania zinkovi-Tynnia precambrica-Striatella coriacea; (16) Kotlin assemblage V with Vendotaenia antiqua-Primoflagella speciose; (17) Mezenia sp., (18) Vendotaenia antiqua. Abbreviations: GSC-General Stratigraphic Chart, RSC-Regional Stratigraphic Chart, LSC-local stratigraphic chart; l-lower, m-middle, $\mathrm{u}$-upper, rov-Rovno Regional Stage, ln-Lontova Horizon; or-Orsha Formation, $\mathrm{D}_{1}$ - Lower Devonian. Depths $(\mathrm{m})$ of boreholes are given to the left of their sections.

\section{LITHOLOGY AND PALEONTOLOGICAL CHARACTERISTICS OF THE VENDIAN DEPOSITS OF THE ORSHA DEPRESSION}

In the north of the Orsha Depression, the Vendian Volyn and Valdai series rest erosively on the MiddleUpper Riphean sandstones of the Orsha Formation and are overlain with stratigraphic discontinuity by the Devonian deposits. The lithological description and paleontological description of regional stratigraphic subdivisions recognized in the sections of Bogushevsk-1, Bogushevsk-2 (Liozno), and Lepel-1 boreholes are given below (Figs. 2, 3).

The stratotype of the Lukoml Formation of the Volyn series was distinguished in the Tolochin-29 borehole (int. 448-517 m), drilled near the village of Proshika (Krupsky district of Minsk oblast), northwest of the

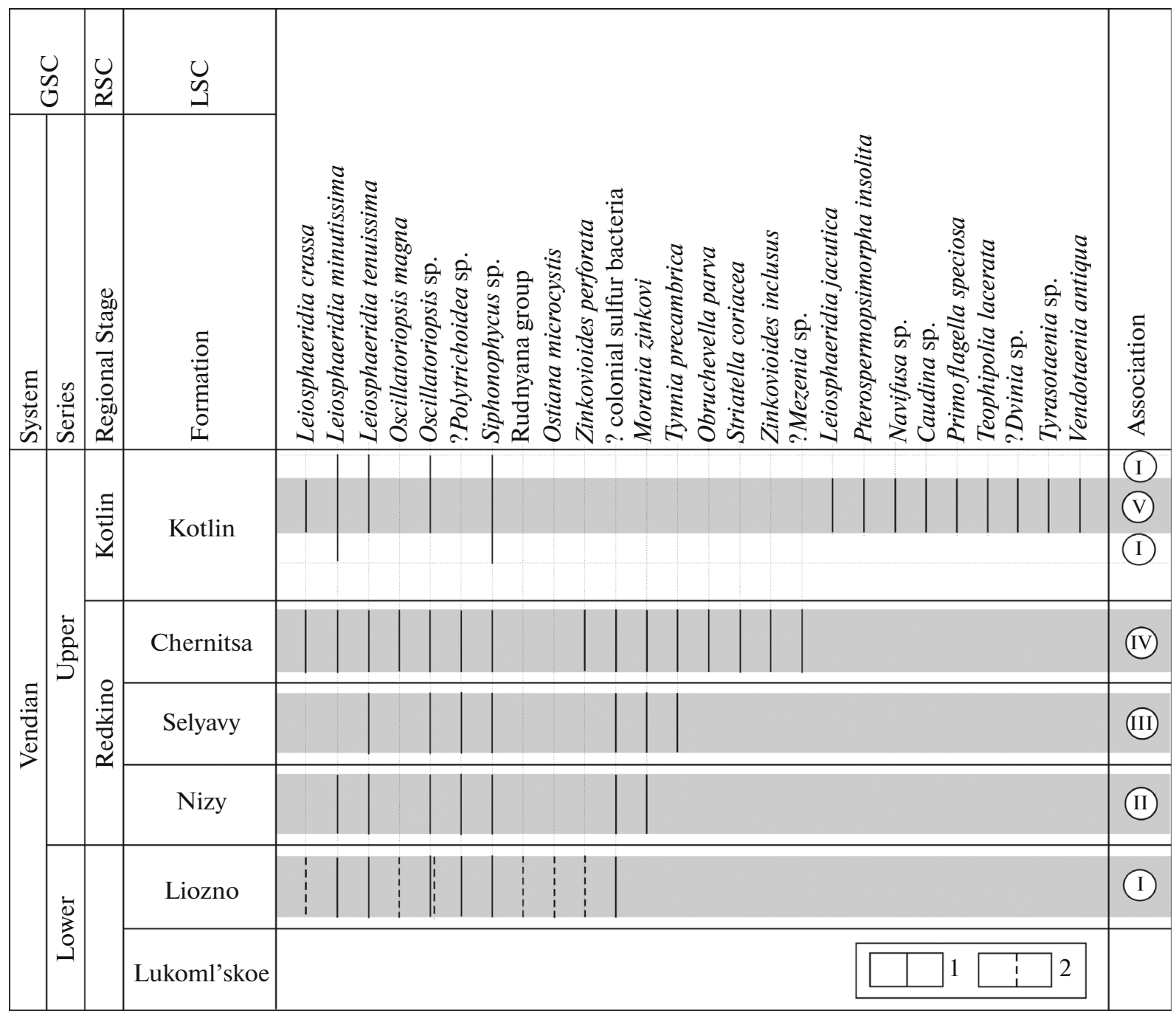

Fig. 3. Taxonomic composition and vertical distribution of fossil organisms from Vendian deposits in the sections of the Bogushevsk-1, Bogushevsk-2 (Liozno), and Lepel-1 boreholes of the Orsha Depression. (1) Our data, (2) after (Piskun, 2013). See other symbols and abbreviations and Fig. 2. 
Orsha Depression (Stratigraficheskie..., 2010). The formation represents the alternation of mudstones, tuff siltstones, and tuff sandstones. The latter dominate in the lower part of the formation. Clays are red, cherry brown, dark gray, micro-laminated, hydromica, sometimes volcanogenic, with a high content of biotite. Tuff siltstones are brown, cherry brown, feldspar-quartz, and micaceous, with fragments of volcanic rocks. Tuff sandstones are coarse- to fine-grained; inequigranular at the base, pale gray, yellowish brown, feldspar-quartz, with an admixture of fragments of basalt glass and effusive rocks.

Transitional microfossils of genera Leiosphaeridia, Ostiana, Synsphaeridium, and Symplassosphaeridium were earlier found in the Borisov-22 (int. 401-385 m) and Tolochin-29 (depth $478 \mathrm{~m}$ ) boreholes (Piskun, 2013). Microfossils were not found in the sample from the upper part of the Lukoml Formation (Bogushevsk-1 borehole) (Fig. 2).

Terrigenous deposits of the Liozno Formation lie conformably on the Lukoml Formation. The stratotype of this formation was distinguished in the Bogushevsk-2 borehole (int. 730-766 m), village of Nizy, Liozno district, Vitebsk oblast (Fig. 2; Stratigraficheskie..., 2010). The lower part of the section is composed of gray and dark gray volcanomictic clayey siltstones with interbeds and lenses of fine-grained gray sandstones and dark gray thinly-laminated micaceous mudstones. Higher in succession, there are bluish gray, yellowish brown, thinly laminated, micaceous mudstones, which gradually pass to clayey siltstones with lenses and interbeds of gray coarse and inequigranular fine-gravel sandstones with clayey (hydromica-kaolinite, kaolinite) and dolomite-clayey cement of basal-porous, rim-pocket, and pocket types.

In the middle part of the Liozno Formation (Bogushevsk-1 borehole), impoverished transitive biota was found and assigned to assemblage I with Leiosphaeridia minutissima-Leiosphaeridia tenuissima (Figs. 2, 3). Hence, single large sphaeromorphic acritarchs Leiosphaeridia tenuissima Eisenack, multicellular trichomes of Oscillatoriopsis sp., filaments of the cell-free structure of Siphonophycus sp., and bundles of filamentous algae of unclear morphological structure attributed under question to the genus Polytrichoides were identified. At this level, specific black formations, recognized on the surface of organic films and filamentous microfossils, are common. The study of morphologically identical forms from the overlying deposits of the Chernitsa Formation under a scanning electron microscope showed that these microfossils represent small (about 5-10 $\mu \mathrm{m}$ ) spherical smooth-walled shells encrusted by pyrite crystals (Plate I, figs. 4, 5). They are supposed to be newly formed mineral formations developed after colonies of sulfur bacteria-destructors (Burzin, 1996, 1998; Sokolov, 1997). Pyrite is present in the composition of the organomacerate.

Piskun (2013) found microfossils Ostiana microcystis Hermann and Zinkovioides perforata Hermann and cyanobacteria Oscillatoriopsis magna Tynni et Donner in deposits of the Liozno Formation (Bogushevsk-2 borehole; int. 751-744.3 m), which are described by the author as Botuobia magna, as well as filamentous algae with characteristic thickenings, attributed to the Rudnyana group (genera Solenophyma, Omalophyma, Kiptophyma, and Isophyma). Clusters of spherical shells were identified in the organomacerate of the sample collected at a depth of $436 \mathrm{~m}$ (Tolochin-29 borehole). They were erroneously attributed to macroscopic dichotomically branching two-row chains Orbisiana simplex Sokolov, emend Kolesnikov, Liu, Danelian, Grazhdankin (Piskun, 2013, Plate I, fig. 9; Plate II, fig. 12).

The Nizy Formation overlies with unconformity the Liozno Formation. The stratotype of the formation was established in the Bogushevsk-2 borehole, int. 694-730 m (Fig. 2; Stratigraficheskie..., 2010). The formation has rhythmic structure. The lower part of rhythms is composed of massive coarse gravel quartzfeldspar; there are light gray and cherry brown volcanomictic sandstones with dolomite and dolomitehematite-kaolinite cement of the basalt type at several layers. The middle part of rhythms is represented by alternation of inequigranular quartz micaceous sandstones and red-brown siltstones and mudstones with thin interbeds of coarse-grained sandstones. The upper part of rhythms is represented by brownish yellow thinly laminated clays with dark brown and ocher yellow spots on the layering surfaces.

Acritarchs of Leiosphaeridia minutissima (Naumova), emend. Jankauskas, L. tenuissima and filamentous algae Oscillatoriopsis sp., Siphonophycus sp., and ? Polytrichoides sp. (Figs. 2, 3; assemblage II with Morania zinkovi) were found in the upper part of the Nizy Formation in Bogushevsk-1 borehole. Specific microorganisms that form a characteristic mesh structure on the surface of acritarchs, algae, and organic films are widely distributed at this stratigraphic level. On the basis of images and descriptions, these forms are identical to the fossil organisms of Morania zinkovi A. Istchenko (Gnilovskaya et al., 1988, p. 30, Plate II, figs. 4,5 ). The latter was described as algal crusts consisting of rounded cells arranged randomly or forming short chains. The study of microfossils at high magnification under biological (Plate I, figs. 1, 2) and electron (Plate I, fig. 3) microscopes showed a different

Plate I. Redkino assemblage of microfossils. (1-3) Microorganisms Morania zinkovi A. Istchenko, developed after acritarchs Leiosphaeridia sp. (1) and organic films (2, 3), Bogushevsk-2 (Liozno) borehole, depth $647 \mathrm{~m}$, spec. L-3: (1a, 1b) slide (sl.) 3/3; (2a, 2b) sl. 3/1; $(4,5)$ ?colonial sulfur bacteria: (4) Bogushevsk-1 borehole, depth $568.5 \mathrm{~m}$, spec. Bog-568.5, sl. 1; (5a, 5b) Bogushevsk-2 (Liozno) borehole, depth 647 m, spec. L-3; (6, 7) Zinkovioides sp.: (6) Bogushevsk-2 (Liozno) borehole, depth $618 \mathrm{~m}$, spec. L-5, sl. 5/2; (7a, 7b) Bogushevsk-2 (Liozno) borehole, depth 617 m, spec. L-6. 


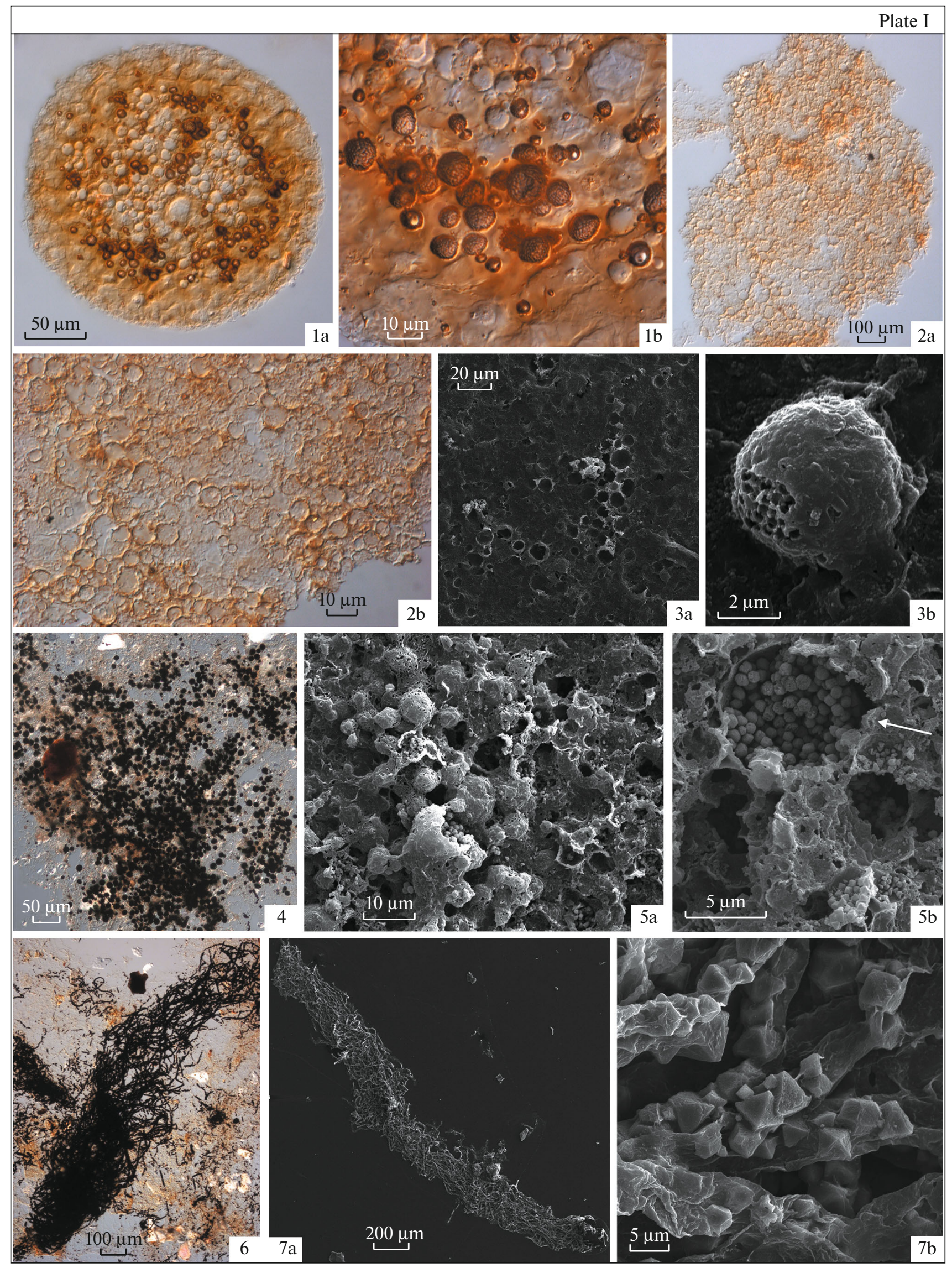


structure than previously assumed. These forms represent a rigid three-dimensional skeleton consisting of small honeycomb cells, which is enclosed in a smooth spherical organic shell. During burial and (or) maceration, these microorganisms were able to detach from the substrate. As a result, rounded pits, which were interpreted previously as cells, remained on the surface of plant films and microfossils (Gnilovskaya et al., 1988). One can assume that these organisms settled on the remains of organisms buried in liquid sediment, forming extended colonies on a nutrient substrate.

The Selyavy Formation lies conformably on the deposits of the Nizy Formation. The stratotype of their formation was distinguished in the Tolochin-29 borehole, int. 338-372 m (Stratigraficheskie..., 2010). The lower part of the formation is composed of fine-grained micaceous arkose sandstones with dolomite-clay (hydromica-kaolinite) cement of the basal-nest type. The deposits are thinly and horizontally layered, with oblique and wavy stratification in the lower part of the unit. The upper part of the formation represents alternation of greenish gray, bluish gray, tobacco yellow thinleaved micaceous siltstones and silty mudstone-like clays of kaolinite-hydromica composition with rare lenslike layers of siderites. Pyritized organic films are common at this level. Massive brown mudstones with interlayers of bright yellow montmorillonite clays (decomposed ash tuffs) were found in the Bogushevsk-2 borehole.

Assemblage III of microfossils with Morania zinkoviTynnia precambrica was found in the Bogushevsk-1 borehole section (Figs. 2, 3). Spheromorphic colonial forms of Tynnia precambrica (Tynni et Donner), emend Burzin, acritarchs Leiosphaeridia tenuissima, and algae Oscillatoriopsis sp., Siphonophycus sp., and ? Polytrichoides sp., as well as abundant unicellular microorganisms Morania zinkovi and proposed colonial sulfur bacteria, were identified here. Scattered pyrite was present in the organomacerate.

The Chernitsa Formation lies conformably on the Selyavy Formation and is overlain transgressively by deposits of the Kotlin Regional Stage. The stratotype of this formation was established in the Bogushevsk-2 borehole section, in int. 600-664 m (Fig. 2; Stratigraficheskie..., 2010). The lower part of the formation is composed of siltstones and inequigranular arkosic (ultrafine- to fine-grained) sandstones with hydromica-kaolinite cement of basal-pocket type. The upper part of the formation is represented by the alternation of hematite-kaolinite-hydromica mudstones and mica siltstones. The rocks are variegated, dark brown to greenish gray, rarely yellowish brown, thinly-laminated with undulating stratification surfaces. There occurs a characteristic ore concentrate of ilmenite and pyrite.

Biotas similar in taxonomic composition, attributed to assemblage IV with Morania zinkovi-Tynnia precambrica-Striatella coriacea, were found in deposits of the Chernitsa Formation in the Bogushevsk-1, Bogushevsk-2 (Liozno), and Lepel-1 boreholes (Figs. 2, 3). Diverse cyanobacteria Obruchevella parva Reitlinger, emend. Yakschin et Luchinina, emend. Burzin (Plate II, figs. 3-6), Oscillatoriopsis magna (Plate II, fig. 8), Siphonophycus sp. (Plate II, fig. 7), Striatella coriacea Assejeva (Plate II, figs. 9, 11), ?Polytrichoides sp. (Plate II, fig. 10), one-celled microorganisms Morania zinkovi (Plate I, figs. 1-3), ?colonial sulfur bacteria (Plate I, figs. 4, 5), and filamentous microfossils Zinkovioides perforata Hermann, Z. inclusus Hermann, and $Z$. sp. are common at this level (Plate I, figs. 6, 7). The last two taxa are interpreted as remains of filamentous sulfur bacteria-destructors (Burzin, 1996, 1998; Sokolov, 1997). Smooth-walled acritarchs Leiosphaeridia crassa (Naumova), emend. Jankauskas, L. minutissima, and L. tenuissima and undefinable plant films occur sporadically. Microfossils Tynnia precambrica (Plate II, figs. 1, 2) were also found in the Bogushevsk-2 (Liozno) borehole. In the Lepel-1 borehole (depth $403 \mathrm{~m}$ ), two fragments of large (up to $7 \mathrm{~mm}$ in diameter) flattened ribbon-shaped macroorganisms of poor preservation close to the genus Mezenia were found. The organomacerate, which is left after dissolution of samples, contains dispersed pyrite.

Along with the above taxa, colonial coccoid forms Ostiana microcystis, filamentous algae Polytrichoides lineatus Hermann and Pomoria rhomboidalis Siverzeva, representatives of the Rudnyana group, and some other taxa were described from the Redkino Regional Stage of Belarus (Piskun, 2013).

The stratotype of the Kotlin Formation and the likenamed regional stage were established in northwestern Russia, in outcrops on Kotlin Island in the Gulf of Finland (Stratigraficheskii..., 1994). The stratotype of the formation is not preserved.

The lower part of the Kotlin Formation is composed of variegated, dark brown, greenish gray, coarse-grained, sporadically gravel, quartz-feldspar sandstones with oblique multidirectional lamination, with lenses and interbeds of bluish gray mudstone-like clays of kaolinite-hydromica composition. At the base of the unit are clay intraclasts and interbeds of quartz-feldspar gravel stones. Frequent mica flakes

Plate II. Redkino assemblage of microfossils. (1, 2) Tynnia precambrica (Tynni et Donner), emend. Burzin, Bogushevsk-2 (Liozno) borehole, depth 623.8 m, spec. Lio-623.8: (1) sl. 3, (2) sl. 1; (3-6) Obruchevella parva Reitlinger, emend. Burzin, Lepel-1 borehole: (3-5) depth 409 m, spec. L2016-5; (3, 5) sl. 1, (4) sl. 2; (6) depth 412 m, spec. L-412, sl. 1; (7) Siphonophycus sp., Bogushevsk-2 (Liozno) borehole, depth $623.8 \mathrm{~m}$, spec. Lio-623.8, sl. 1; (8) Oscillatoriopsis magna Tynni et Donner, Bogushevsk-2 (Liozno) borehole, depth $623.8 \mathrm{~m}$, spec. Lio-623.8, sl. 1; (9, 11) Striatella coriacea Assejeva: (9) Lepel-1 borehole, depth $405.8 \mathrm{~m}$, spec. L2016-8, sl. 1; (11) Bogushevsk-2 (Liozno) borehole, depth 623.8 m, spec. Lio-623.8, sl. 3; (10a, 10b) ? Polytrichoides sp., Lepel-1 borehole, depth 409 m, spec. L2016-5, sl. 1. 


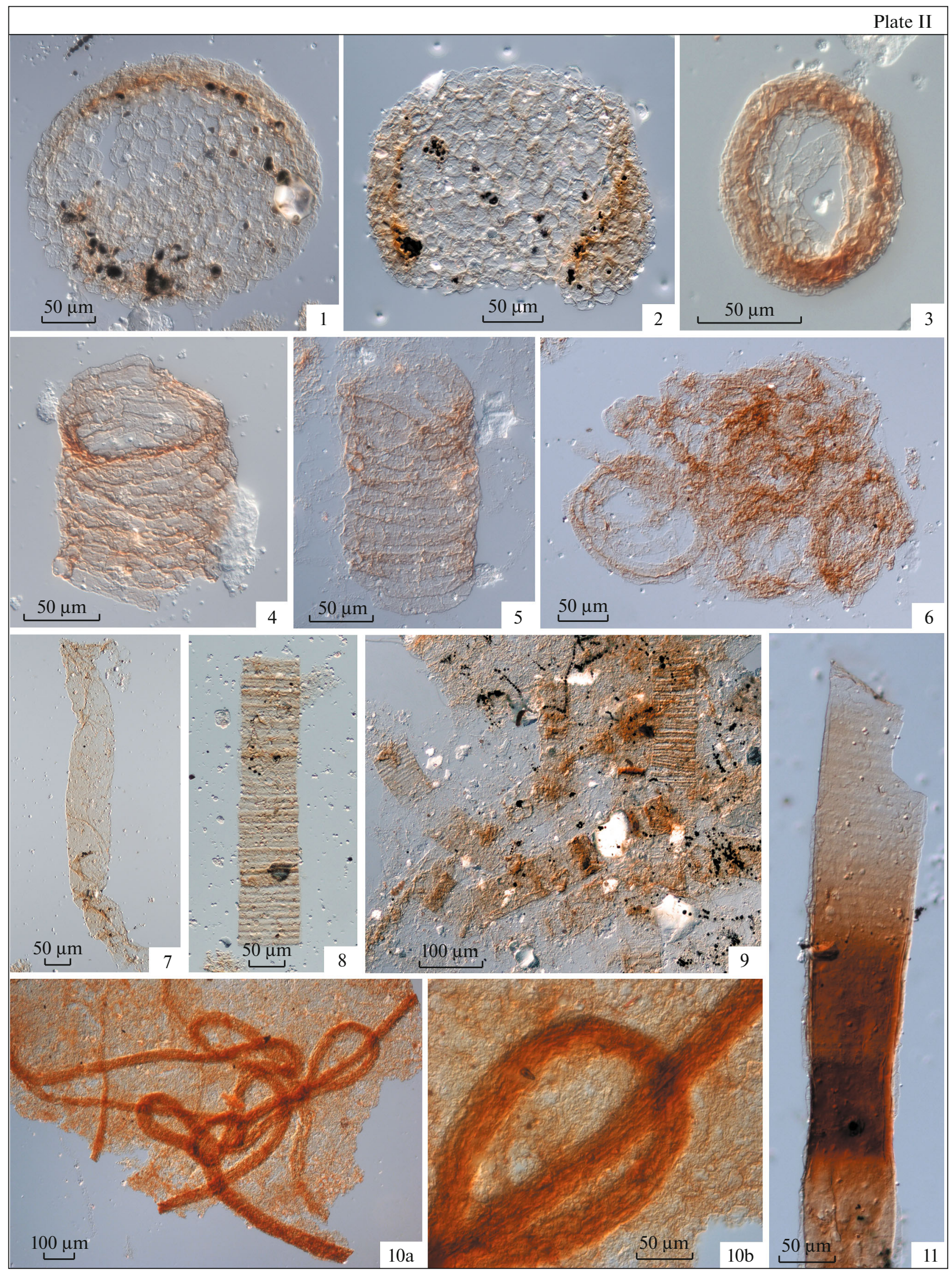


and silty powdering and thin impregnation of pyrite are noted on interlayer surfaces mudstones of the Bogushevsk-1 borehole. Microfossils were not found at this stratigraphic level (Fig. 2).

The middle part of the formation represents alternation of kaolinite-hydromica silty clays, micaceous (scales up to 2-3 $\mathrm{mm}$ ) siltstones, and arkose sandstones inequigranular ultrafine- and fine-grained (up to gravels with a grain size up to $2 \mathrm{~mm}$ ), with clayey (kaolinite, hydromica-kaolinite, ferruginous-kaolinite), carbonate-clayey (dolomite-, siderite-kaolinite), and kaolinite-dolomite cement of nest and nestbasal type. The rocks are variegated, greenish gray to brown-dark brown, horizontally thin-layered, thickslabby, with wavy stratification surfaces with elements of oblique, wedge-shaped, cross, lenticular layering, with pinches and swells, which is emphasized by the presence of mica in layers with a thickness of 1-4 mm. Single transitive microfossils Leiosphaeridia minutissima, Siphonophycus sp. (Figs. 2, 3; assemblage I with Leiosphaeridia minutissima-Leiosphaeridia tenuissima) were found at the same level in Bogushevsk-1 borehole (depth $536.7 \mathrm{~m}$ ).

The upper part of the formation is composed of gray, brownish gray, thinly bedded, and also silty clays of kaolinite-hydromica and chlorite-kaolinitehydromica composition in the lower part. Clays contain black and dark brown organic films, as well as pyrite nodules and concretions. In general, this unit is characterized by the presence of thin $(0.1-2 \mathrm{~cm}$ thick) interbeds and lenses of carbonate (siderite), siltysandy-carbonate, and carbonate-terrigenous rocks of brown to yellow-brown color.

A relatively rich biota attributed to assemblage $\mathrm{V}$ with Vendotaenia antiqua-Primoflagella speciosa was found at a depth of $517.6 \mathrm{~m}$ in the Bogushevsk-1 borehole (Figs. 2, 3). It includes widespread macroscopic filamentous algae Vendotaenia antiqua Gnilovskaya (Plate III, fig. 4), fragments of which were found on interlayer surfaces and in the organomacerate obtained during the dissolution of rocks. The characteristic representatives of this assemblage are actinomycetes Primoflagella speciosa Gnilovskaya (Plate III, figs. 9, 10), developed after organic films and vendothenium algae buried in the sediment thickness (Plate III, figs. 6, 7,9). Filamentous algae with a massive thick wall (?Dvinia sp.) and a thin elastic layer (Tyrasotaenia sp.), spheromorphic acritarchs Leiosphaeridia jacutica (B. V. Timofeev) emend. Mikhailova et Jankauskas, L. minutissima (Plate III, fig. 1), L. tenuissima
(Plate III, fig. 2), and cyanobacteria Siphonophycus sp. and a single oval shell with an opening (?pylome) Teophipolia lacerata Kirjanov occur sporadically (Plate III, fig. 3). Of considerable interest are the finds of large tubular organisms with smoothly rounded ends, which are attributed to Caudina sp. (Plate III, figs. 5, 6, 11). The revealed forms consist of a dense inner body and an outer thin elastic shell.

Impoverished biota, assigned under question to assemblage $\mathrm{V}$, was found in the Bogushevsk-2 (Liozno) borehole (int. 553.4-548.4 m) (Figs. 2, 3). Problematics Caudina sp. (Plate III, fig. 7), two-layered shells Pterospermopsimorpha insolita B.V. Timofeev, emend. Mikhailova, acritarchs of genera Leiosphaeridia and Navifusa, and cyanobacteria Siphonophycus sp. and Oscillatoriopsis sp. were identified here. Higher in the section, in the Bogushevsk-1 and Bogushevsk-2 (Liozno) boreholes, single transitive microfossils Leiosphaeridia minutissima, L. tenuissima, and Siphonophycus sp. (Fig. 2, assemblage I with Leiosphaeridia minutissima-Leiosphaeridia tenuissima) were found.

Microfossils Polytrichoides lineatus, Pomoria rhomboidalis, and Ostiana microcystis and single Zinkovioides perforata were described previously from the Kotlin Formation in the Orsha Depression (Orsha-4 borehole) of Belarus (Piskun, 2013; Piskun et al., 2000). Macroscopic algae Vendotaenia antiqua and actinomycetes Primoflagella speciosa were found in the Kotlin Formation exposed in the Drissa (int. 537$341.9 \mathrm{~m}$ ) and Kupa (int. 330-338 m) boreholes of the Belarussian Anteclise (Gnilovskaya et al., 1988).

\section{BIOSTRATIGRAPHIC DISTRIBUTION OF FOSSIL ORGANISMS}

Analysis of the vertical distribution of microfossils in the Vendian deposits of the Orsha Depression allowed us to make a set of summaries. There are no microfossils, or there are single transitive taxa (assemblage I) in samples collected from mudstones of the Liozno Formation of the Volyn Series. Piskun (2013) found Zinkovioides perforata, Oscillatoriopsis magna, and representatives of the Rudnyana group at this stratigraphic level and the overlying deposits of the Redkino Regional Stage. Microorganisms Zinkovioides perforata are known from the Redkino Regional Stage of the Yaryshivska Formation of Ukraine (Sokolov, 1997; Vendskaya..., 1985a); single finds are known from the Kotlin Regional Stage of Belarus (Piskun, 2013). The large cyanobacteria Oscillatoriop-

Plate III. Kotlin assemblage of microfossils. (1) Leiosphaeridia minutissima (Naumova), emend. Jankauskas, Bogushevsk-2 (Liozno) borehole, depth 548.4 m, spec. Lio-548.4, sl. 4; (2) Leiosphaeridia tenuissima Eisenack, Bogushevsk-2 (Liozno) borehole, depth 553.2 m, spec. Lio-553.2, sl. 3; (3) Teophipolia lacerata Kirjanov, Bogushevsk-1 borehole, depth 517.6 m, spec. Bog-517.6, sl. 2; (4) Vendotaenia antiqua Gnilovskaya, Bogushevsk-1 borehole, depth 517.6 m, spec. Bog-517.6, sl. 6; (5-7, 11) Caudina sp.: (5, $6 \mathrm{a}, 6 \mathrm{~b})$ dense inner body, enclosed in the outer thin shell; (11) outer shell, Bogushevsk-1 borehole, depth 517.6 m; spec. Bog-517.6, sl. 1; (7) Bogushevsk-2 (Liozno) borehole, depth $553.4 \mathrm{~m}$, spec. Lio-553.4, sl. 2; (8) ?budding of microfossils of unknown origin, Bogushevsk-1 borehole, depth 517.6 m, spec. Bog-517.6, sl. 5; (9, 10) Primoflagella speciosa Gnilovskaya, Bogushevsk-1 borehole, depth $517.6 \mathrm{~m}$, spec. Bog-517.6: (9) sl. 6; (10) sl. 2. 


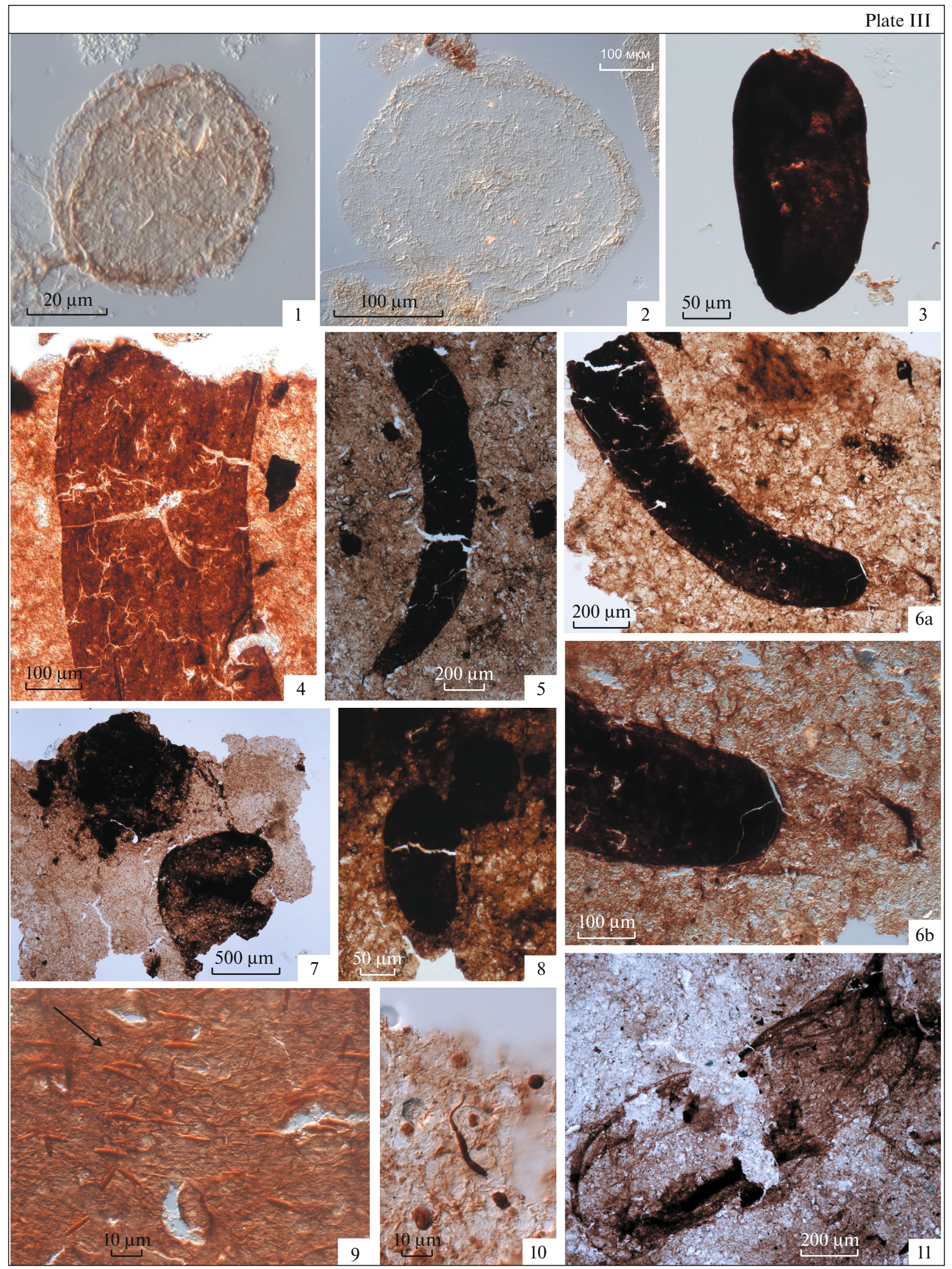


sis magna are widespread in deposits of the Redkino Regional Stage of the EEP (Microfossilii..., 1989; Vendskaya..., 1985a; etc.), and representatives of the Rudnyana group are widespread in the Redkino Regional Stage of the EEP and the Urals (Microfossilii..., 1989) and in the Vendian of the Katanga Saddle of Eastern Siberia (Stratigrafiya..., 2005). The paleontological data obtained by our predecessors are not enough to assign the Liozno Formation to the Redkino Regional Stage. Nevertheless, the presence of common taxa in the upper part of the Volyn and Valdai series, as well as pyrite, may indicate similar conditions that existed in the paleobasin (paleobasins) of this time and, possibly, at a single stage in the evolution of organic-walled microfossils. To solve this issue, additional sampling of mudstones of the Volyn series for micropaleontological study is necessary.

The Selyavy, Nizy, and Chernitsa formations contain taxa typical of deposits of the Redkino Regional Stage of the EEP (assemblages II-IV). Cyanobacteria Striatella coriacea were earlier described from Redkino Regional Stage of European Russia (Vendskaya..., 1985). Sphaeromorphic colonies of Tynnia precambrica are known from the Redkino Regional Stage of Ukraine and Leningrad and Arkhangelsk oblasts of Russia and the Upper Vendian of Finland (Burzin, 1997; Golubkova et al., 2018). Filamentous ?sulfur bacteria Zinkovioides inclusus were found in the Redkino Regional Stage of the Yaryshivska Formation of Ukraine (Sokolov, 1997; Vendskaya..., 1985a) and the Starorusskaya Formation of Leningrad oblast (Golubkova et al., 2018). One-celled microorganisms Morania zinkovi were described from the Yaryshivska Formation of Podolia (Gnilovskaya et al., 1988). Macrofossils Mezenia kossovoyi Sokolov are common in the Redkino Regional Stage of the north of European Russia (Sokolov, 1997) and the Perevalok Formation of the Middle Urals (Grazhdankin et al., 2007). The coiled microfossils Obruchevella parva are known from the Upper Vendian-Lower Cambrian deposits worldwide. However, the abundant finds come only from the deposits of the Redkino Regional Stage of EEP (Burzin, 1995). The rest of the taxa have a wide stratigraphic interval of distribution. According to the taxonomic composition, the third Selyavy and fourth Chernitsa assemblages are correlated with the first Redkino biota established in the Starorusskaya Formation in the Shotkusa-1 borehole of Leningrad oblast (Golubkova et al., 2018).

The overlying deposits of the Kotlin Formation include assemblage V with Vendotaenia antiqua-Primoflagella speciosa (Fig. 2). This assemblage contains abundant macroscopic algae Vendotaenia antiqua and fungi-destructors Primoflagella speciosa, which are characteristic representatives of the Kotlin biotas of the EEP (Gnilovskaya et al., 1988; Vendskaya..., 1985a; Vokova et al., 1979; etc.). The problematic Teophipolia lacerata found at this stratigraphic level was previously considered an index species of the Rovno
Regional Stage (Pashkavichene, 1980; Vendskaya..., 1985a; Volkova et al., 1979). However, these forms were later found in the Kanilov Formation of the Kotlin Regional Stage in Ukraine (Burzin, 1995). Two-layered tubular organisms of genus Caudina were described from the Redkino Regional Stage of the Moscow Syneclise (Volkova et al., 1979). On the basis of the taxonomic composition, assemblage $\mathrm{V}$ is correlated with the third Kotlin biota, found in the Vasileostrovskaya Formation of Leningrad oblast of northwestern Russia (Golubkova et al., 2020).

\section{CONCLUSIONS}

Our studies made it possible to update the paleontological characteristics of the Vendian deposits of the Orsha Depression of the EEP. Taxonomically diverse assemblages of fossil microorganisms were identified in the reference sections of the Bogushevsk-1, Bogushevsk-2 (Liozno), and Lepel-1 boreholes. Impoverished transitional biotas (assemblage I with Leiosphaeridia minutissima-Leiosphaeridia tenuissima) were found in the Liozno and Kotlin formations. This may be evidence of conditions in water basins unfavorable for the development and (or) burial of more complexly organized communities of organisms.

Terrigenous strata of the Nizy, Selyavy, and Chernitsa formations contain the second (with Morania zinkovi), the third (with Morania zinkovi-Tynnia precambrica), and the fourth (with Morania zinkoviTynnia precambrica-Striatella coriacea) Redkino assemblages, respectively. They contain abundant specific microorganisms Morania zinkovi, which are unknown in northwestern Russia but are found in the Podolia sections (Gnilovskaya et al., 1988; Golubkova et al., 2018). Assemblages III and IV include the following taxa (Mezenia, Obruchevella parva, Tynnia precambrica, Zinkovioides inclusus), typical of deposits of the Redkino Regional Stage in the north of European Russia. A significant rearrangement in the assemblages occurred in the Kotlin time. Assemblage V with Vendotaenia antiqua-Primoflagella speciosa was found in the clayey unit of the Kotlin Formation. In general, the taxonomic diversity of the Kotlin assemblage of the Orsha Depression is lower than in northwestern Russia. Several typical taxa are absent here. Among them are Aataenia, Bicuspidata, Cochleatina, and Vanavarataenia, typical of the deposits of the Kotlin Regional Stage of the Leningrad oblast.

In terms of taxonomy, assemblages III and IV are correlated with the first Redkino biota in the Starorusskaya Formation, and assemblage $\mathrm{V}$ is correlated with the third Kotlin biota in the Vasileostrovskaya Formation of northwestern Russia. This indicates a high correlation potential of fossil microorganisms. Our results show the potential of using the paleontological method to subdivide, correlate, and date the Upper Vending deposits and inspire a certain amount of optimism relative to the possibility of the develop- 
ment of unified biostratigraphic criteria for distinguishing regional stratigraphic subdivisions in the updated stratigraphic scheme of the EEP.

\section{FUNDING}

This work was supported by the Russian Foundation for Basic Research (project no. 20-05-00427).

\section{CONFLICT OF INTERESTS}

Authors do not have any conflict of interest.

\section{OPEN ACCESS}

This article is licensed under a Creative Commons Attribution 4.0 International License, which permits use, sharing, adaptation, distribution and reproduction in any medium or format, as long as you give appropriate credit to the original author(s) and the source, provide a link to the Creative Commons license, and indicate if changes were made. The images or other third party material in this article are included in the article's Creative Commons license, unless indicated otherwise in a credit line to the material. If material is not included in the article's Creative Commons license and your intended use is not permitted by statutory regulation or exceeds the permitted use, you will need to obtain permission directly from the copyright holder. To view a copy of this license, visit http://creativecommons.org/licenses/by/4.0/.

Reviewers N.G. Vorob'eva, K.E. Nagovitsyn, and N.B. Kuznetsov

\section{REFERENCES}

Braiser, M.D., Cowie, J., and Taylor, M., Decision on the Precambrian-Cambrian boundary stratotype, Episodes, 1994, vol. 17, nos. 1-2, pp. 3-8.

Burzin, M.B., Late Vendian helicoids filamentous microfossils, Paleontol. J., 1995, vol. 29, no. 1A, pp. 1-34.

Burzin, M.B., Are ansient organisms a source of oil in the Russian Platform? Priroda, 1996, no. 2, pp. 38-42.

Burzin, M.B., Tynnia Burzin, gen. nov.: A new genus of the Vendian colonial coccoidal organic-walled microfossils, Paleontol. Zh., 1997, no. 2, pp. 20-28.

Burzin, M.B., Late Vendian Paleobiogeography in the Russian Platform, in Paleogeografiya venda-rannego paleozoya Severnoi Evrazii. Sb. nauch. trudov (Coll. Sci. Works. "Paleogeography of the Vendian-Early Paleozoic of North Eurasia"), Ekaterinburg: Ural. Otd. Ross. Akad. Nauk, 1998, pp. 136-146.

Compston, W., Sambridge, M.S., and Reinfrank, R.F., Numerical ages of volcanics and the earliest faunal zone within the Late Precambrian of East Poland, J. Geol. Soc., 1995, no. 152 , pp. 599-611.

Dopolneniya $k$ stratigraficheskomu kodeksu Rossii. Utochnenie otsenok izotopnogo vozrasta nizhnikh granits verkhnego rifeya, venda, verkhnego venda i kembriya. Dopolnenie 4 (Supplement to the Stratigraphic Code of Russia. Clarification of Isotope Ages of Lower boundaries of Upper Riphean, Vendian, Upper Vendian. Suppl. 4), St. Petersburg: Vseross. Nauchno-Issled. Geol. Inst., 2000, pp. 95-107.
Fedonkin, M.A., Belomorskaya biota venda (dokembriiskaya besskeletnaya fauna severa Russkoi platformy) (Belomorian Biota of the Vendian: Precambrian Soft-Bodied Fauna of the Northern Russian Platform), Moscow: Nauka, 1981 [in Russian].

Gehling, J.G., Jensen, S., Droser, M.L., Myrow, P.M., and Narbonne, G.M., Burrowing below the basal Cambrian GSSP, Fortune Head, Newfoundland, Geol. Mag., 2001, vol. 138, pp. 213-218.

Geologiya Belarusi (Geology of Belarus), Makhnach, A.S., Garetsky, R.G., and Matveev, A.V., Eds., Minsk: Inst. Geol. Nauk NAN Belarusi, 2001 [in Russian].

Gnilovskaya, M.B., Ishchenko, A.A., Kolesnikov, Ch.M., Korenchuk, L.V., and Udal'tsov, A.P., Vendotenidy Vostochno-Evropeiskoi platformy (Vendotenids of the East European Platform), Leningrad: Nauka, 1988 [in Russian].

Golubkova, E.Yu., Kushim, E.A., Kuznetsov, A.B., Yanovskii, A.B., Maslov, A.V., Shvedov, S.D., and Plotkina, Yu.V., Redkinian Biota of Macroscopic Fossils from the Northwestern East European Platform (South Ladoga Region), Dokl. Earth Sci., 2018, vol. 479, no. 1, pp. 300-304.

Golubkova, E.Yu., Kushim, E.A., and Tarasenko, A.B., Fossil organisms of the Kotlin Regional Stage of the Upper Vendian of the northwestern Russian Platform (Leningrad Region), Paleontol. J., 2020, vol. 55, no. 4, pp. 420-428.

Gradstein, F.M., Ogg, J.G., Schmitz, M.D., and Ogg, G.M., Geological Time Scale, Elsevier, 2020.

Grazhdankin, D.V., Structure and sedimentation conditions of the Vendian complex of the southeastern White Sea, Stratigr. Geol. Korrel., 2003, vol. 11, no. 4, pp. 3-23.

Grazhdankin, D., Patterns of evolution of the Ediacaran soft-bodied biota, J. Paleontol., 2014, vol. 88, no. 2, pp. 269-283.

Grazhdankin, D.V. and Maslov, A.V., The room for the Vendian in the International Chronostratigraphic Chart, Russ. Geol. Geophys., 2015, vol. 56, no. 4, pp. 549-559.

Grazhdankin, D.V., Nagovitsin, K.E., and Maslov, A.V., Late Vendian Miaohe-type ecological assemblage of the East European platform, Dokl. Earth Sci., 2007, vol. 417, no. 1, pp. 1183-1187.

Kuz'menkova, O.F., Nosova, A.A., and Shumlyanskii, L.V., Comparison of the Neo-Proterozoic Volhynia-Brest magmatic province with large provinces of continental plateau basalts of the world, nature of low- and high-titanium basic magmatism, Litasfera, 2010, vol. 2, no. 33, pp. 3-16.

Landing, E., Precambrian-Cambrian boundary global stratotype ratified and new perspective of Cambrian time, Geology, 1994, vol. 22, no. 2, pp. 179-182.

Makhnach, A.S. and Veretennikov, N.V., The Vendian of Belarus as one of the priority stratotypes of the Vendian system of the East European Platform, Dokl. Nats. Akad. Nauk Belarusi, 2001, vol. 45, no. 2, pp. 123-126.

Makhnach, A.S. and Veretennikov, N.V., Vulkanogennaya formatsiya verkhnego proterozoya (venda) Belorussii (Volcanic Formation of the Upper Proterozoic (Vendian) of Belarus), Minsk: Nauka Tekhn., 1970 [in Russian]

Makhnach, A.S., Shkuratov, V.I., Zinovenko, G.V., and Piskun, L.V., Kembrii Belarusi (Cambrian of Belarus), Minsk: Nauka Tekhn., 1985 [in Russian].

Makhnach, A.S., Veretennikov, N.V., Shkuratov, V.I., Laptsevich, A.G., and Piskun, L.V., Stratigraphic chart of Vendian deposits of Belarus, Litasfera, 2005a, vol. 1, no. 22, pp. 36-43. 
Makhnach, A.S., Zinovenko, G.V., Abramenko, V.I., and Piskun, L.V., Stratigraphic chart of Vendian deposits of Belarus, Litasfera, 2005b, vol. 1, no. 22, pp. 44-52.

Mikrofossilii dokembriya SSSR (Precambrian Microfossils of the USSR), Yankauskas, T.V., Ed., Leningrad: Nauka, 1989 [in Russian].

Narbonne, G.M., Xiao, S., and Shields, G., The Ediacaran Period, in Geologic Timescale 2012, Gradstein, F., Ogg, J., Schimitz, M.D., and Ogg, G. Eds., Boston: Elsevier, 2012, pp. 413-435.

Nosova, A.A., Kuz'menkova, O.F., Veretennikov, N.V., Petrova, L.G., and Levskii, L.K., Neoproterozoic Volhynia-Brest magmatic province in the western East European craton: Within-plate magmatism in an ancient suture zone, Petrology, 2008, vol. 16, no. 2, pp. 105-135.

Nosova, A.A., Kuz'menkova, O.F., and Shumlyanskyy, L.V., Age and origin of crustal protolith of felsic effusives of the Volhynia-Brest Province, the west of the East European Platform, in Mater. XI Vseross. petrogr. soveshch. "Magmatizm $i$ metamorfizm $v$ istorii Zemli" (Proc. XI All-Russ. Petrogr. Conf. "Magmatism and Metamorphism in the Earth's History"), Ekaterinburg: Inst. Geol. Geokhim. Ural. Otd. Ross. Akad. Nauk, 2010, vol. 2, pp. 103-104.

Pashkavichene, L.T., Akritarkhi pogranichnykh otlozhenii venda $i$ kembriya zapada Vostochno-Evropeiskoi platformy (Acritarchs from the Vendian and Cambrian Boundary Deposits of the West of the East European Platform), Moscow: Nauka, 1980 [in Russian].

Paszkowski, M., Budzyń, B., Mazur, S., Sláma, J., Shumlyanskyy, L., Środoń, J., Dhuime, B., Kędzior, A., Liivamägi, S., and Pisarzowska, A., Detrital zircon $\mathrm{U}-\mathrm{Pb}$ and $\mathrm{Hf}$ constraints on provenance and timing of deposition of the Mesoproterozoic to Cambrian sedimentary cover of the East European Craton, Belarus, Precambrian Res., 2019, vol. 331, pp. 1-19.

Piskun, L.V., Mikrofossilii venda Belarusi (Vendian Microfossils of Belarus), Minsk, 2013 [in Russian].

Piskun, L.V., Laptsevich, A.G., Makhnach, A.S., Veretennikov, and N.V., Paleophytologic description of the Kotlin horizon of the Vendian of Belarus, Litasfera, 2000, no. 13, pp. 38-46.

Postanovleniya Mezhvedomstvennogo stratigraficheskogo komiteta i ego postoyannykh komissii. Vyp. 18 (Resolutions of Interdepartmental Committee and Its Permanent Commissions. Vol. 18), Leningrad: Vseross. Nauchno-Issled. Geol. Inst., 1992 [in Russian].

Rifei $i$ vend Belarusi (Riphean and Vendian of Belarus), Makhnach, A.S., Veretennikov, N.V., Shkuratov, V.I., and Bordon, V.E., Eds., Minsk: Nauka Tekhn., 1976 [in Russian]. Semikhatov, M.A., Shurkin, K.A., Aksenov, E.M., Bekker, Yu.R., Bibikova, E.V., Duk, V.L., Esipchuk, K.E., Karsakov, L.P., Kiselev, V.V., Kozlov, V.I., LobachZhuchenko, S.B., Negrutsa, V.Z., Robonen, V.I., Sez'ko, A.I., Filatova, L.I., Khomentovsky, V.V., Shemyakin, V.M., and Shul'diner, V.I., New stratigraphic chart of the Precambrian of the USSR, Izv. Akad. Nauk SSSR. Ser. Geol., 1991, no. 4, pp. 3-13.

Semikhatov, M.A., Kuznetsov, A.B., and Chumakov, N.M., Isotope age of boundaries between the general stratigraphic subdivisions of the Upper Proterozoic (Riphean and Vendian) in Russia: The evolution of opinions and the current estimate, Stratigr. Geol. Correl., 2015, vol. 23, no. 6, pp. 568-579. Shkuratov, V.I. and Makhnach, A.S., Paleogeographic conditions of sedimentation in Valdai time of the Vendian in Belarus, Dokl. NAN Belarusi, 2003, vol. 47, no. 4, pp. $104-106$.
Shumlyanskyy, L., Nosova, A., Billström, K., Söderlund, U., Andréasson, Per-G., and Kuzmenkova, O., The U-Pb zircon and baddeleyite ages of the Neoproterozoic Volyn Large Igneous Province: implication for the age of the magmatism and the nature of a crustal contaminant, GFF, 2016, vol. 138, no. 1, pp. 17-30.

Sokolov, B.S., Vendian of the Russian Platform: subdivisions and stratigraphic analogs, in Tez. dokl. Soveshch. po verkhnemu dokembriyu (rifeyu) Russkoi platformy (Proc. Conf. on Upper Precambrian (Riphean) of the Russian Platform), Moscow: Nauka, 1974, pp. 3-10.

Sokolov, B.S., Ocherki stanovleniya venda (Essays on the Establishment of the Vendian), Moscow: KMK Ltd., 1997 [in Russian].

Sokolov, B.S., Vendian System: Precambrian geobiological environment, in Tr. Mezhd. geol. kongr. XXVI sess. Dokl. sov. geologov. Paleontologiya. Stratigrafiya (Proc. Int. Geol. Congr. XXVI Sess. Reports of Soviet Geologists. Paleontology. Stratigraphy), Moscow: Nauka, 1980, pp. 9-21.

Stratigrafiya neftegazonosnykh basseinov Sibiri. Rifei i vend Sibirskoi platformy i ee skladchatogo obramleniya (Stratigraphy of Petroleum Basins of Siberia. Riphean and Vendian of the Siberian Platform and its Folded Frame), Kontorovich, A.E., Ed., Novosibirsk: GEO, 2005 [in Russian].

Stratigraficheskaya skhema vendskikh otlozhenii Moskovskoi sineklizy. Ob"yasnitel'naya zapiska (Stratigraphic Scheme of the Vendian Deposits of the Moscow Syneclise. Explanatory Noty), Moscow, 1996 [in Russian].

Stratigraficheskie skhemy dokembriiskikh i fanerozoiskikh otlozhenii Belarusi: ob"yasnitel'naya zapiska (Stratigraphic Schemes of the Precambrian and Phanerozoic Rocks in Belarus. Explanatory Note), Minsk: GP “BelNIGRI”, 2010 [in Russian].

Stratigraficheskii slovar': Verkhnii vend (Severnaya Evraziya v granitsakh byvshego SSSR) (Stratigraphic Dictionary: Upper Vendian (Northern Eurasia within the Former USSR)), Moscow: Nauka, 1994 [in Russian].

Vendskaya sistema. Istoriko-geologicheskoe i paleontologicheskoe obosnovanie. T. 1. Paleontologiya (Vendian System. Historical, Geological, and Paleontological Foundation. Vol. 1: Paleontology), Sokolov, B.S. and Fedonkin, M.A., Eds., Moscow: Nauka, 1985a [in Russian].

Vendskaya sistema. Istoriko-geologicheskoe i paleontologicheskoe obosnovanie. T. 2. Stratigrafiya i geologicheskie protsessy (Vendian System. Historical, Geological, and Paleontological Foundation. Vol. 1: Stratigraphy and Geological Processes), Sokolov, B.S. and Fedonkin, M.A., Eds., Moscow: Nauka, 1985b [in Russian].

Volkova, N.A., Gnilovskaya, M.B., Palii, V.V., Lendzien, K., Kiryanov, V.V., Palii, V.M., Pashkavichene, L.T., Piskun, L.V., Posti, E., Rozanov, A.Yu., Urbanek, A., Fedonkin, M.A., and Jankauskas, T.V., Paleontologiya verkhnedokembriiskikh $i$ kembriiskikh otlozhenii Vostochno-Evropeiskoi platformy (Paleontology of Upper Precambrian and Cambrian Deposits of the East European Platform), Moscow: Nauka, 1979 [in Russian].

Zaitseva, T.S., Kuznetsov, A.B., Gorozhanin, V.M., Gorokhov, I.M., Ivanovskaya, T.A., and Konstantinova, G.V., The Lower boundary of the Vendian in the Southern Urals as evidenced by the $\mathrm{Rb}-\mathrm{Sr}$ age of glauconites of the Bakeevo Formation, Stratigr. Geol. Correl., 2019, vol. 27, no. 5, pp. 573-587.

Translated by D. Voroshchuk 